\title{
Modeling of reproduction in the intertidal macrophyte Fucus vesiculosus and implications for spatial subsidies in the nearshore environment
}

\author{
J. F. Muhlin ${ }^{1,4, *}$, M. A. Coleman ${ }^{1,2}$, T. A. V. $\operatorname{Rees}^{3}$, S. H. Brawley ${ }^{1}$ \\ ${ }^{1}$ School of Marine Sciences, University of Maine, Orono, Maine 04469, USA \\ ${ }^{2}$ New South Wales Marine Parks Authority, Batemans Marine Park. Burrawang St., Narooma, New South Wales 2546, Australia \\ ${ }^{3}$ Leigh Marine Laboratory, University of Auckland, Warkworth, Northland 0941, New Zealand \\ ${ }^{4}$ Present address: Maine Maritime Academy, 206 Dirigo House, Castine, Maine 04420, USA
}

\begin{abstract}
Environmental sensitivities that represent reproductive adaptations are well enough known in some species of marine broadcast spawners, including fucoid algae, to consider wider ecological implications of gamete release. Here, we test and refine a preliminary model for gamete release in the intertidal foundation species Fucus vesiculosus L., one of the most abundant broadcast spawners of the North Atlantic rocky shore. Local environmental conditions and levels of gamete release were determined during 2 reproductive seasons at 4 sites on the Schoodic Peninsula (Maine, USA). These studies supported the hypothesis that asynchrony in the incidence and magnitude of natural gamete release occur when environmental conditions (i.e. light, water motion) across projections of the coastline are uneven. Gamete release occurs on sunny days when winds speeds are $<6.6 \mathrm{~m} \mathrm{~s}^{-1}$. Using these data, we modeled historical meteorological data for part of the Gulf of Maine (GOM) to hindcast gamete release in F. vesiculosus. The regional model predicted that gamete release increased at many GOM sites over $22 \mathrm{yr}$ (1985-2006). Combining local fucoid density, zone width, and linear coastline data with $\mathrm{C}$ and $\mathrm{N}$ analysis of eggs, we found that fucoid egg release is an uncharacterized subsidy available to many trophic levels, which is pulsed into the nearshore GOM. Our results provide important insights into the consequences of ocean-climate variability on biological processes.
\end{abstract}

KEY WORDS: Broadcast spawning - Fucoid algae - Fucus - Gamete release - Gametophagy · Gulf of Maine $\cdot$ Intertidal $\cdot$ Reproductive ecology $\cdot$ Reproductive modeling $\cdot$ Spatial subsidy

\section{INTRODUCTION}

The sea and intertidal zone have fluctuating hydrodynamic regimes that represent a potentially strong barrier to successful fertilization in broadcast spawners; yet, external fertilization is common in marine algae and invertebrates. To analyze the basis for fertilization success and to model it, understanding the reproductive adaptations of marine broadcast spawners to life in the sea appears to be essential. Factors such as circannual, lunar, and semilunar rhythms; photoperiod; and temperature regulate gametogenesis (Giese \& Kanatani 1987, Brawley \& Johnson 1992), but the final trigger for gamete release is one or more environmental and/or biological cues to which adults are sensitive. Many of these adaptive cues are shared among particular species of algae and invertebrates, and they include spectral or intensity changes in light, sharp temperature or salinity change, seasonal phytoplankton blooms (invertebrates), nutrient limitation (algae), behaviors (invertebrates), low water motion, and pheromones 
(e.g. Thorson 1950, Harrison et al. 1984, Babcock et al. 1986, Starr et al. 1990, 1992, 1993, Brawley 1992, Brawley \& Johnson 1992, Minchin 1992, BartelsHardege et al. 1996, Bonardelli et al. 1996, Pearson \& Brawley 1996, Serrão et al. 1996, Clifton \& Clifton 1999, Berndt et al. 2002, Marshall 2002, Marshall et al. 2004, Himmelman et al. 2008, Lüning et al. 2008, Levitan et al. 2011). Adaptive gamete traits that either concentrate gametes or prevent polyspermy (= lethal, multiple fertilizations) are also shared across algae and invertebrates, including phototaxis, buoyancy, pheromone secretion by eggs to attract sperm, gamete release in mucilage, gamete longevity, the electrical fast block against polyspermy, and the secretion-based permanent block against polyspermy (e.g. Babcock et al. 1986, Brawley 1991, Brawley \& Johnson 1992, Sewell \& Levitan 1992, Johnson \& Brawley 1998, Meidel \& Yund 2001, Marshall 2002, Williams \& Bentley 2002, Yund \& Meidel 2003, Marshall et al. 2004, Riffell \& Zimmer 2007, Yund et al. 2007, Manríquez \& Castilla 2010). In at least one organism (an ascidian), different qualities (e.g. size) of gametes were produced by adults in high- versus low-density populations; the different types of gametes were associated with better reproductive success in each case, which demonstrates how well-coupled adaptive mechanisms appear to be (Crean \& Marshall 2008). Consideration of these adaptations helps to explain the typically high fertilization success in nature that is documented among marine broadcast spawners (i.e. 80 to $100 \%$ fertilization; Brawley 1992, Berndt et al. 2002, Franke et al. 2003 [see their Table 1], discussion in Gaudette et al. 2006). This supports Thorson's views (1950) on the larval stage as the bottleneck in the life history of these organisms (NB, Brawley \& Johnson 1991), and is in sharp contrast to predictions of low fertilization success where adults were artificially spawned in experimental field studies, a technique that bypasses suites of adult and gamete behaviors.

The rapidly expanding mechanistic knowledge of reproductive adaptations suggests that it will soon be possible to model the timing and periodicity of gamete release in diverse marine organisms (NB, Gaudette et al. 2006, Himmelman et al. 2008) to elucidate larger ecological effects. One of the best understood groups is fucoid algae ('rockweeds'), which have many reproductive adaptations that are considered in the model that is tested and refined below. For example, fucoid eggs are negatively buoyant, while sperm are negatively phototaxic and attracted to eggs by a well-characterized octatriene pheromone (Maier \& Müller 1986). Further, gamete release under sunny, calm(er) conditions prevents gamete dilution and produces high natural fertilization success $(\sim 100 \%$; see review by Pearson \& Serrão 2006) with low polyspermy $(\sim 2 \%)$ except in low salinity populations (i.e. upper estuarine Fucus ceranoides and F. vesiculosus and Baltic Sea F. vesiculosus and F. radicans, where the sodium-dependent, electrical polyspermy block fails; see Brawley 1992, Serrão et al. 1999). Fucoid adults release gametes during calmer, sunny periods as a consequence of a boundary layer-bicarbonate sensing mechanism for water motion that is tied to photosynthesis; a bluelight sensor also regulates gamete release, perhaps because of sensing of spectral shifts associated with the deeper (and often calmer) water that fucoids experience during much of high tide (Pearson et al. 1998, 2004). There is exquisite sensitivity to water motion (Serrão et al. 1996, Pearson \& Brawley 1998); thus, the few hours of photosynthesis required under calm conditions to trigger gamete release form a potentiation period that can be reversed completely by application of turbulent conditions. These analyses and a field study of gamete release and fertilization success in F. vesiculosus L., led to a preliminary model (Berndt et al. 2002) for gamete release based upon thresholds of water motion and irradiance sufficient for photosynthesis. Berndt et al. (2002) also determined the natural sperm:egg ratio in this dioecious species (= separate male and female individuals) and found that gamete release and fertilization were essentially synchronous near slack high tide.

A prediction of the Berndt et al. (2002) model was that fucoid populations living along a topographically irregular coastline may release gametes asynchronously over relatively short distances due to spatially asynchronous conditions of light or water motion. For example, on the Maine shore there are many peninsulas that run north to south; winds from the west or east would be predicted by the model to cause gamete release (or more release of gametes) on one side of such a peninsula on days that are neither fully sunny and calm (= gamete release predicted on both sides) nor fully cloudy with high wave motion (= gamete release predicted not to occur on either side). It is already known that maturation of gametes in Fucus vesiculosus occurs with semilunar periodicity near full and new moons, but mature gametes are held indefinitely when stormy weather occurs during the $\pm 2 \mathrm{~d}$ period around spring tides when gamete release is known to occur under calm(er), sunny conditions (Berndt et al. 2002). Most fucoid gametes available for release in any 2 wk period can be released on a single day if a particularly calm, sunny 
day occurs (Brawley 1992, Serrão et al. 1996, Berndt et al. 2002). Here, we test the asymmetric release hypothesis from the Berndt et al. (2002) model at 4 sites on the Schoodic Peninsula of the Maine coast, expand it to a regional scale in the Gulf of Maine (GOM), and consider whether gamete release represents an important spatial subsidy.

Variation in both reproductive timing and output may have direct effects on the nearshore community and coastal ecosystem. Given that Fucus vesiculosus is among the most abundant and conspicuous intertidal seaweeds on Atlantic shores, eggs, sperm, and reproductive mucilage that are released during reproduction may constitute a large and uncharacterized spatial subsidy to nearshore ecosystems, providing a food source for filter feeders, grazers, and detritivores, and a subsidy that some trophic levels might be adapted to anticipate. A spatial subsidy, sensu Polis et al. (1997), is movement of energy or nutrients from a donor habitat that increases productivity within a recipient habitat. Much spatial subsidy research has focused on movement of nutrients via detritus, which contributes substantially to nutrient fluxes (e.g. Findlay \& Tenore 1982, Storry et al. 2006) and consumer responses (Duggins \& Eckman 1994, Kelaher \& Levinton 2003, Bishop et al. 2010, Spiller et al. 2010). Gamete spatial subsidies and gametophagy or oophagy are reported (e.g. Galvão et al. 1989, Minchin 1992, Järnegren et al. 2005, Dumont et al. 2008), but ecosystem-level effects are described mainly in the context of the mass spawning of corals on the Great Barrier Reef. There, strong trophic links with fish gametophagy are known (e.g. Pratchett et al. 2001), and surplus reproductive material represents a large energy and nutrient input to reef communities that stimulates microbial degradation pathways (sometimes deleteriously; Simpson et al. 1993) and phytoplankton blooms (Wild et al. 2008). Despite the well-appreciated importance of omnivorous grazers on fucoid recruitment in the intertidal zone (e.g. Lubchenco \& Menge 1978, Lubchenco 1983, Vadas \& Elner 1992), the quantity and effects of fucoid gamete release on nearshore environments vis-a-vis a spatial subsidy are unknown. Here, we estimate the potential contribution of $F$. vesiculosus eggs to nearshore carbon and nitrogen pulses per 2 wk period at Schoodic Point (ME). Using preliminary data, we evaluate the extent to which egg release and zygote settlement is correlated. In addition, we apply our model of reproduction for $F$. vesiculosus to historical meteorological data at multiple stations within the GOM to explore the response of a biological process (i.e. reproduction) to climate variability.

\section{MATERIALS AND METHODS}

Gamete release from Fucus vesiculosus L. was examined at 4 sites at Schoodic Point $\left(44^{\circ} 20^{\prime} \mathrm{N}, 68^{\circ} 03^{\prime} \mathrm{W}\right)$, Acadia National Park, Maine (USA), in 2003 and 2004. F. vesiculosus reproduces predominantly from early September to late December on the coast of Maine (and much of the GOM). To consider the effect of asynchronous environmental conditions, 2 sites were located on the western side and 2 on the eastern side of Schoodic Point (Fig. 1, inset). Topographic characteristics of Schoodic Point prohibit sites within a side from being identical with respect to wind conditions. Specifically, the NE site was predicted to be more sheltered than the SE site during easterly winds due to an offshore island nearby. In addition, all locations were predicted to be sheltered from northern winds by the large landmass to the north (Fig. 1). The NW site was relocated to a similar shoreline $\sim 400 \mathrm{~m}$ south in 2004 due to local ice scour of $F$. vesiculosus at the 2003 site.

A pumping station (detailed in Berndt et al. 2002) was deployed in the mid-intertidal zone at each site to collect oogonia, eggs, and sperm at $1 \mathrm{~h}$ intervals for $\sim 6 \mathrm{~h}$ during high tide. Each pumping station consisted of a bilge pump powered by a $12 \mathrm{~V}$ battery that was attached via anchored polypropylene lines to 3 collection funnels. Collection funnels were randomly placed along a transect line in the mid-intertidal

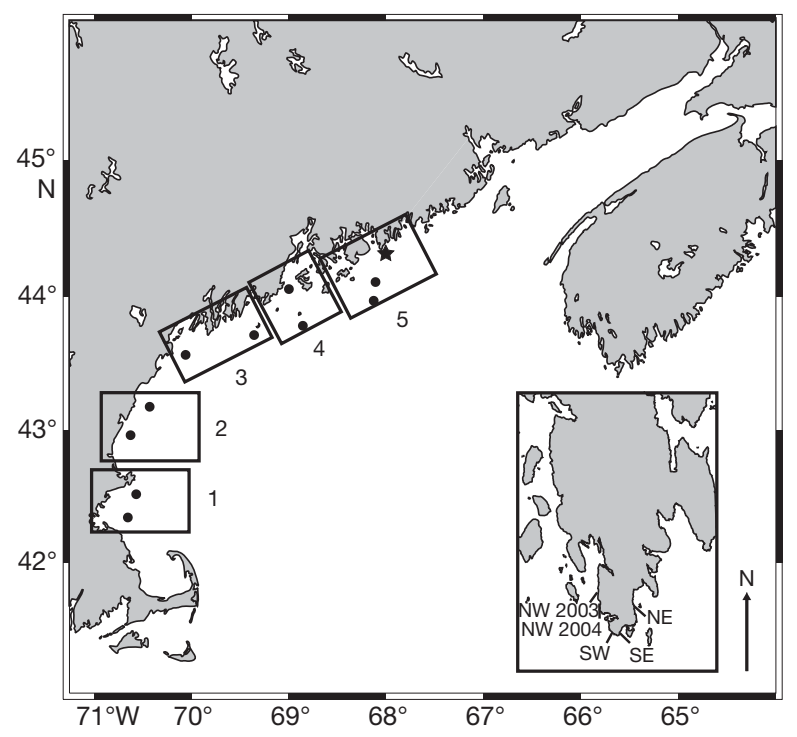

Fig. 1. Gulf of Maine (GOM) with Schoodic Point, ME,( $\star$ ). Inset with the location of field experiments at Schoodic Point; NW and SW sites located on the western side and NE and SE sites on the eastern side. The GOM was divided into 5 regional locations (1-5) used in hindcast analyses with Gulf of Maine Ocean Observing System (GoMOOS) buoys and National Oceanographic and Atmospheric Administration (NOAA) C-MAN stations $(\bullet)$ 
zone, 2 to $10 \mathrm{~m}$ apart. Funnels were covered in $2 \times$ $2 \mathrm{~cm}$ mesh and were $15 \mathrm{~cm}$ above the substratum within the Fucus vesiculosus canopy. Samples were pumped through the lines to a filtration apparatus (>1 $\mu \mathrm{m})$ that retained samples (Berndt et al. 2002).

Collection times were standardized to $t=0$ which was defined as the time when funnels $(n=3)$ at each site were immersed; actual times of collection varied slightly between sites because funnels were not immersed simultaneously when collections began due to wind (i.e. wave height variability). Samples $(n=3)$ for each hourly interval were collected sequentially for $5 \mathrm{~min}$ at a rate of $1.91 \mathrm{~min}^{-1}$ at each pumping station. A $120 \mathrm{ml}$ aliquot of each sample was fixed (final concentration: $2 \%$ formaldehyde, $0.2 \%$ glutaraldehyde; Electron Microscopy Sciences) immediately after collection. Lines and filtration apparatus were purged of previous sample before collecting a new sample.

Fixed samples were concentrated to approximately $2.5 \mathrm{ml}$ in the laboratory via vacuum filtration with 1.2 $\mu \mathrm{m}$ Millipore filters (Berndt et al. 2002). The number of eggs for each sample was determined by enumerating all eggs in a $90 \mu$ subsample with brightfield microscopy $(100 \times)$ and counts were extrapolated to eggs $1^{-1}$. On a subset of samples, sperm were quantified by indirect immunofluorescence using monoclonal antibody 144.6, developed against Fucus vesiculosus sperm (Berndt et al. 2002), to demonstrate that sperm were released when egg release was detected (Muhlin 2007). For model analyses, only egg data were utilized.

A pilot study investigated the relationship between gamete release and settlement of eggs and zygotes at the NW and NE sites over several days in 2003 and 2004. Settlement plates $\left(28.3 \mathrm{~cm}^{2}\right)$ with rough surfaces were cast from Sea Goin' Poxy Putty (Permalite Plastics) and pretreated to remove plastic residues per Brawley \& Johnson (1991). Replicate plates were haphazardly placed within the middle of the Fucus vesiculosus zone and secured to the substratum using stainless steel screws. Plates were set out at the low tide prior to sampling gamete release at high tide and collected immediately following emersion. Plates were returned to the laboratory and settled eggs and zygotes counted in 10 fields of view $\left(F O V=9 \mathrm{~mm}^{2}\right)$ per plate.

\section{Environmental sampling}

Three methods were used to characterize hydrodynamic conditions at each site on days when reproduction was measured; clod cards, Beaufort sea state, and a Marsh-McBirney electromagnetic current meter. Plaster of Paris clod cards (Thompson \& Glenn 1994) measured relative time-integrated water motion at each site. Clod cards were pre-weighed and fastened by cable ties to the polypropylene lines $\sim 10 \mathrm{~cm}$ shoreward of each collection funnel. Time of immersion and emersion of each clod card was noted. After $72 \mathrm{~h}$ of drying $\left(65^{\circ} \mathrm{C}\right)$, clod cards $(\mathrm{n}=3)$ were reweighed to establish weight lost by dissolution as average weight loss $\left(\mathrm{g} \mathrm{h}^{-1}\right.$ site $\left.^{-1}\right)$. To compare clod card loss against local water motion at a collection site, a Marsh-McBirney current meter (Model 511, Marsh-McBirney) was anchored ca. $0.5 \mathrm{~m}$ above the substratum within the Fucus vesiculosus bed concurrently with replicate clod cards at either the NE or NW site over 4 d in 2004 and 2006. Current velocities were measured at a full scale of $2 \mathrm{~m} \mathrm{~s}^{-1}$ at $0.2 \mathrm{~Hz}$.

Beaufort sea state was recorded when samples were collected at each site. The Beaufort sea state/ wind scale is the oldest method to measure wind force (Hasse \& Smith 1997), and this measure of water motion provided a consistent method to assess local sea state. The Beaufort scale is categorical (i.e. each integer category relates to a range of wind speeds but one general sea state); for each site, a daily mean Beaufort value was calculated from 6 hourly values. Because the mean value ranged between the categorical integers, a calibration curve was established to estimate the wind speed $\left(\mathrm{m} \mathrm{s}^{-1}\right)$ for Beaufort values between categories.

In addition to hydrodynamic conditions, we measured light levels (photon flux density, PFD, $\mu \mathrm{mol}$ photons $\mathrm{m}^{-2} \mathrm{~s}^{-1}$ ) with either a Li-Cor Underwater Quantum sensor (Model LI-192SA, Li-Cor) or a Skye quantum sensor (Model 385233, Skye Instruments) at 2 to 4 collection sites. Occasionally only 2 sensors were available, but measurements were made at sites on opposite sides of Schoodic Point throughout the study. Simultaneous air and underwater PFDs were measured to compare light levels at the height of the immersed fucoid canopy compared to above-water (surface) PFD. Light levels are greatly reduced (ca. 50\%) in water compared to above-water measurements (see 'Results'). To evaluate whether sufficient light for photosynthesis was present (i.e. full light potentiation) to permit gamete release in the fucoid canopy, we measured the light levels at the surface over $3 \mathrm{~h}$ leading to slack high tide, the time during which Fucus vesiculosus beds are completely immersed. The light levels obtained at each site were averaged and translated into 4 numerical categories (0 to 3 ). The average surface irradiance level that could potentiate receptacles was defined as $300 \mu \mathrm{mol}$ photons $\mathrm{m}^{-2} \mathrm{~s}^{-1}$. This value corre- 
sponds to an underwater 'high light' irradiance value in laboratory experiments (e.g. Major \& Davison 1998) and natural levels of irradiance during gamete release in field data (see 'Results' and Berndt et al. 2002). Categories corresponded to $0=0-200 \mu \mathrm{mol}$ photons $\mathrm{m}^{-2}$ $\mathrm{s}^{-1}, 1=201-300 \mu \mathrm{mol}$ photons $\mathrm{m}^{-2} \mathrm{~s}^{-1}, 2=301-$ $500 \mu \mathrm{mol}$ photons $\mathrm{m}^{-2} \mathrm{~s}^{-1}$, and $3=\geq 501 \mu \mathrm{mol}$ photons $\mathrm{m}^{-2} \mathrm{~s}^{-1}$. Field and laboratory data show that irradiance at Categories 2 and 3 will potentiate receptacles for gamete release (Pearson et al. 1998 and references therein). Category 1 corresponds to low light conditions in the field, which still may allow some reproduction but is close to a level at which potentiation does not occur (i.e. Category 0).

Environmental data for wind direction and wind speed were collected from Buoy 1, the nearest Gulf of Maine Ocean Observing System (www.GoMOOS. org) buoy to Schoodic Point, for each sampling day from 06:00 to 16:00 h EST. Vector plots of wind direction and wind speed were used to evaluate and define the permissive or restrictive wind conditions for gamete release.

\section{Data analyses}

Egg concentration values were log-transformed to achieve homoscedascity for analysis of variance (ANOVA). For each day of sampling, sites were nested within side of Point (east or west) or nested by exposure (north or south), depending on the prevailing wind conditions. Thus, each day was analyzed separately in a 1-way ANOVA because environmental conditions were independent for each day.

Correlation and regression analyses (linear and logistic) assessed relationships between gamete release and environmental conditions, and were used to define the threshold wind speed value for gamete release. For comparisons of gamete release with zygote settlement, data were $\ln (x+1)$ transformed. To test for correlations between number of eggs released and number of zygotes settled, we pooled site and time data and performed a Pearson's correlation. Statistical tests were performed with SYSTAT version 11.0 (Systat Software) and JMP version 7.0 (SAS Institute). Statistical differences were inferred using $\mathrm{p} \leq 0.05$ unless otherwise specified.

\section{Carbon and nitrogen content in fucoid eggs}

Fucus vesiculosus was collected from the mid- to low-intertidal zone at 3 sites at or close to Schoodic
Point (ME) in December 2003. The sites were Newport Cove $\left(44^{\circ} 20^{\prime} \mathrm{N}, 68^{\circ} 11^{\prime} \mathrm{W}\right)$, Ledges $\left(44^{\circ} 21^{\prime} \mathrm{N}\right.$, $\left.68^{\circ} 04^{\prime} \mathrm{W}\right)$, and Seawall $\left(44^{\circ} 15^{\prime} \mathrm{N}, 68^{\circ} 17^{\prime} \mathrm{W}\right)$. At least 20 fertile individuals were haphazardly collected within $50 \mathrm{~m}$ of each other at each site and were stored in polythene bags in darkness at $4^{\circ} \mathrm{C}$ for 1 to $9 \mathrm{~d}$ before processing.

For each site, 5 females were selected and all receptacles were removed. Excised receptacles for each individual were placed in 10 to $50 \mathrm{ml}$ seawater and incubated in light $\left(80 \mu \mathrm{mol}\right.$ photons $\left.\mathrm{m}^{-2} \mathrm{~s}^{-1}\right)$ at $10^{\circ} \mathrm{C}$ for $5 \mathrm{~h}$ to allow release of eggs. Eggs were resuspended, and the total number present in 5 separate 2 to $30 \mu l$ portions was counted using a Sedgewick Rafter cell. Mean egg numbers were divided by the volume used and multiplied by the total volume of seawater to give total egg number released. The eggs were allowed to settle, and the remaining seawater was aspirated until about 1 to $2 \mathrm{ml}$ remained. After aspiration, eggs were resuspended in 1 to $2 \mathrm{ml}$ seawater, placed in a preweighed, oven-dried $\left(80^{\circ} \mathrm{C}\right.$ for at least $\left.24 \mathrm{~h}\right)$ microcentrifuge tube and centrifuged at $87 \times g$ for $1 \mathrm{~min}$. The supernatant was removed, and the egg pellet dried as above. Dried eggs were stored at $-20^{\circ} \mathrm{C}$ prior to analysis of carbon and nitrogen content. The carbon and nitrogen content of eggs was determined using a Carlo-Erba 1106 CHNOS analyzer. Differences in egg carbon and nitrogen content between sites were analyzed using 1-way ANOVA. Where ANOVAs indicated significant differences, post-hoc multiple comparisons were performed using multiple comparison Tukey's tests. All nutrient data analyses were performed using SigmaPlot version 11.0 (Systat Software) and p $<0.05$.

\section{The model and a regional model of reproduction}

A model to evaluate the spatial and temporal variability of gamete release from Fucus vesiculosus in the GOM was developed. Threshold values from the data collected in the field portion of this study (irradiance, wind speed [Beaufort force], and wind direction) were used to define restrictive and permissive periods for gamete release and to hindcast when reproduction may have occurred using archival meteorological data. The model was applied to 5 regions throughout the GOM (Fig. 1): (1) Boston, MA; (2) Portsmouth, NH; (3) Portland, ME; (4) Penobscot Bay, ME (in the vicinity of Rockland, ME); and (5) Bar Harbor, ME, that were established by proximity to a GoMOOS buoy (www.GoMOOS.org) or a National Oceanic and Atmospheric Administration (NOAA) C-MAN station (www.ndbc.noaa.gov). 
Regional spatial and temporal variability of reproduction was evaluated by running the model for all 5 regions with historical data (1985-2006). Five days surrounding new and full moons were compiled for each month of the reproductive season (September through December, approximately $10 \mathrm{~d} \mathrm{mo}^{-1}$ ), because under permissive environmental conditions, gamete release occurs twice a month near new and full moons (Berndt et al. 2002). Sunrise and high tide data were obtained (Eldridge Pilot and Tide Tables 1985-2006), and days were excluded if there were fewer than $3.5 \mathrm{~h}$ of sunlight prior to high tide, which is required to provide sufficient photosynthesis to deplete dissolved inorganic carbon in the boundary layer (Pearson et al. 1998). Environmental data for average wind speed and wind direction during 06:00 to 16:00 h EST (Regions 1-5, 1985-2001) came from the National Data Buoy Center (www.ndbc. noaa.gov) and, in 2002-2006 used GoMOOS buoy data (graphing and download commands, www. GoMOOS.org). Wind directions were categorized as north for 316 to $360^{\circ}$ and 1 to $45^{\circ}$, east for 46 to $135^{\circ}$, south for 136 to $225^{\circ}$, and west for 226 to $315^{\circ}$. Cloud cover (measure of irradiance) was obtained from land-based meteorological archives (National Weather Service data on www.wunderground.com). Irradiance was qualitatively categorized as overcast, foggy, precipitation (rain, sleet, snow), mostly cloudy, partly cloudy/mostly sunny, or sunny. For each day, hourly environmental conditions were averaged for 06:00 to 16:00 $\mathrm{h}$ EST. If irradiance was $>75 \%$ (see Berndt et al. 2002) partly cloudy/mostly sunny or sunny, the day was permissive for gamete release. Reproduction was hindcast to occur if a particular set of conditions was present. If levels of irradiance were not permissive (<75\% partly sunny/sunny) and wind speed was above the threshold value, reproduction was hindcast to not occur. If irradiance was above threshold values ( $>75 \%$ partly sunny/sunny) and wind speed was below the threshold values (i.e. calm), reproduction was hindcast to occur synchronously on both sides of a coastal promontory. If irradiance was permissive but wind speed was above the threshold value, asynchronous reproduction was hindcast to occur across a coastal promontory.

\section{Calculating the potential spatial subsidy of egg release at Schoodic Point}

We calculated the potential subsidy associated with the $14 \mathrm{~d}$ semilunar cycle of gamete release, which can be pulsed into the nearshore environment on a single day or over several days, depending upon environmental conditions. Egg carbon and nitrogen in released eggs $\left(\mathrm{mg}\right.$ ind.$^{-1}$ ) determined for Fucus vesiculosus was multiplied by average density and zone width to result in $\mathrm{g} \mathrm{C} \mathrm{m}^{-1}$ coastline or $\mathrm{g} \mathrm{N} \mathrm{m}^{-1}$ coastline. Density of individuals $\mathrm{m}^{-2}$ was divided in half, because the sex ratio for this species is $1: 1$ within the region (Serrão et al. 1999, Muhlin 2007). Zone width and $F$. vesiculosus density within a representative location at Schoodic Point was determined by placing a $100 \mathrm{~m}$ transect line perpendicular to the shore. Three randomly chosen transects were measured from the top of the $F$. vesiculosus zone to the bottom, including any rises or dips in topography. Fucoid density in the middle of each transect was determined by counting reproductive individuals within 6 , randomly chosen $0.25 \mathrm{~m}^{2}$ quadrats. The linear coastline of Schoodic Point (m) was measured with the Google Earth distance calculator.

\section{RESULTS}

\section{Asynchronous gamete release occurs with asynchronous environmental conditions}

Over the 2003 and 2004 field seasons, complete data on gamete release were obtained for 10 out of 18 d sampled over all 4 collection sites. Incomplete data resulted from logistical problems (e.g. very cold days when pumping lines froze). The 10 sampling days fell within 6 tidal cycles (different new and full moon periods) and gamete release on 5 of these tidal cycles fit the Berndt et al. (2002) model. On 3 of the 10 d sampled (27 September 2003, 10 November 2003, 13 October 2004), there were significant differences in egg concentrations on the eastern versus western sides of Schoodic Point associated with asymmetrical environmental conditions across the Point (Table 1, Fig. 2). One day (11 October 2003) experienced significantly different levels of gamete release at northern versus southern sites. No gametes were present in samples from 26 October 2003; this day had strong, sustained winds from the south (Fig. 2), low light levels (overcast with irradiance levels ca. $100 \mu \mathrm{mol}$ photons $\mathrm{m}^{-2} \mathrm{~s}^{-1}$ ), and high levels of water motion (Beaufort forces ranging from a mean of 3.1 to 3.4), and was therefore consistent with environmental conditions predicted to inhibit gamete release (Berndt et al. 2002). Two days (26 September 2003 and 14 October 2004) were calm and sunny and had high gamete release everywhere (Table 1, Fig. 2); 14 October 2004 trends towards a north-south 
asynchrony, although this trend is not statistically significant (Table 1). During the sixth tidal cycle studied $(27,28$, and 29 October 2004) gamete release did not fit the Berndt et al. (2002) model because gamete release was high despite strong northern winds and low light at some sites.

Asynchronous gamete release on opposite sides of Schoodic Point occurred with strong easterly or westerly winds. On 10 November 2003 and 13 October 2004 , there were strong winds from the west, resulting in significantly lower levels of reproduction at western sites (Fig. 2, Table 1). In contrast, 27 September 2003 had winds from the east that resulted in significantly higher levels of gamete release at the western sites. Asynchronous reproduction at northern versus southern sites occurred on 11 October 2003. This day had lighter winds from the south (Fig. 2). Stronger southern winds were demonstrated to create more unfavorable conditions at all sites (e.g. 26 October 2003). As predicted due to sheltering topography, when there was an eastern wind
(27 September 2003, 14 October 2004, 29 October 2004), there were higher levels of gametes released at the NE site compared to the SE site (Fig. 2). When we examine each site for each day by model predictions of Berndt et al. (2002), the model predicts the likelihood of gamete release $72 \%$ of the time (Appendix 1).

\section{Correlation between gamete release and settlement}

Some settlement of zygotes occurred when gametes were released. No zygote settlement was found at a site on days when gamete release did not occur, as assayed in samples from the water column. In general, when gamete release did occur, settlement of zygotes was orders of magnitude lower than the number of eggs that were released. The number of eggs released correlated with the number of zygotes settled $(\mathrm{df}=10, \mathrm{r}=0.41, \mathrm{p}<0.05)$.
Table 1. Nested analyses of variance testing for differences between sides (east versus west, north versus south) and differences between sites within sides. Significant $\mathrm{p}$-values $(\mathrm{p} \leq 0.05)$ are indicated in bold

\begin{tabular}{|c|c|c|c|c|c|}
\hline Date & Source & df & MS & $F$ & $\mathrm{p}$ \\
\hline \multirow[t]{3}{*}{26 Sep 2003} & Side (EW) & 1 & 0.540 & 0.455 & 0.519 \\
\hline & Site (Side) & 2 & 3.717 & 3.731 & 0.099 \\
\hline & Residual & 8 & 1.187 & & \\
\hline \multirow[t]{3}{*}{27 Sep 2003} & Side (EW) & 1 & 6.061 & 6.697 & 0.032 \\
\hline & Site (Side) & 2 & 1.546 & 1.708 & 0.241 \\
\hline & Residual & 8 & 0.905 & & \\
\hline \multirow[t]{3}{*}{11 Oct 2003} & Side (NS) & 1 & 0.845 & 28.21 & 0.001 \\
\hline & Site (Side) & 2 & 0.132 & 4.413 & 0.051 \\
\hline & Residual & 8 & 0.030 & & \\
\hline \multirow[t]{3}{*}{10 Nov 2003} & Side (EW) & 1 & 20.52 & 28.21 & 0.001 \\
\hline & Site (Side) & 2 & 2.808 & 3.860 & 0.067 \\
\hline & Residual & 8 & 0.727 & & \\
\hline \multirow[t]{3}{*}{13 Oct 2004} & Side (EW) & 1 & 21.76 & 32.26 & $<0.001$ \\
\hline & Site (Side) & 2 & 0.660 & 1.099 & 0.379 \\
\hline & Residual & 8 & 0.600 & & \\
\hline \multirow[t]{3}{*}{14 Oct 2004} & Side (NS) & 1 & 7.088 & 3.953 & 0.082 \\
\hline & Site (Side) & 2 & 0.548 & 0.255 & 0.781 \\
\hline & Residual & 8 & 1.793 & & \\
\hline \multirow[t]{3}{*}{27 Oct 2004} & Side (EW) & 1 & 0.583 & 1 & 0.347 \\
\hline & Site (Side) & 2 & 0.583 & 1 & 0.410 \\
\hline & Residual & 8 & 0.583 & & \\
\hline \multirow[t]{3}{*}{28 Oct 2004} & Side (NS) & 1 & 0.886 & 0.341 & 0.575 \\
\hline & Site (Side) & 2 & 0.957 & 0.368 & 0.703 \\
\hline & Residual & 8 & 2.599 & & \\
\hline \multirow[t]{3}{*}{29 Oct 2004} & Side (NS) & 1 & 7.675 & 3.304 & 0.107 \\
\hline & Site (Side) & 2 & 1.204 & 0.519 & 0.614 \\
\hline & Residual & 8 & 2.323 & & \\
\hline
\end{tabular}

\section{Water motion and light levels to establish threshold values for gamete release}

All measures of water motion (clod card, Beaufort, and current meter) demonstrated a negative relationship between the level of water motion and gamete release. The amount of gamete release was negatively related to the Beaufort sea state (linear regression, adjusted $\mathrm{r}^{2}=0.40, \mathrm{p}<$ 0.001). Analyses of clod-card data found a negative relationship overall (Spearman's rank coefficient $=-0.36$, $\mathrm{p}<0.001$ ).

Simultaneous above-water and within-canopy light measurements revealed that PFD was approximately one-half the light intensity documented at the surface. There were 3 sampling dates at the SE site for comparisons between mean $( \pm \mathrm{SE})$ surface irradiance and irradiance experienced at the level of the receptacles underwater. For 13 October 2004, PFD was $708 \pm 130 \mu \mathrm{mol}$ photons $\mathrm{m}^{-2}$ $\mathrm{s}^{-1}$ (aerial) vs. $329 \pm 51 \mu \mathrm{mol}$ photons $\mathrm{m}^{-2} \mathrm{~s}^{-1}$ (canopy); $1003 \pm 132 \mu \mathrm{mol}$ photons $\mathrm{m}^{-2} \mathrm{~s}^{-1}$ (aerial) vs. $531 \pm$ 
A Egg release

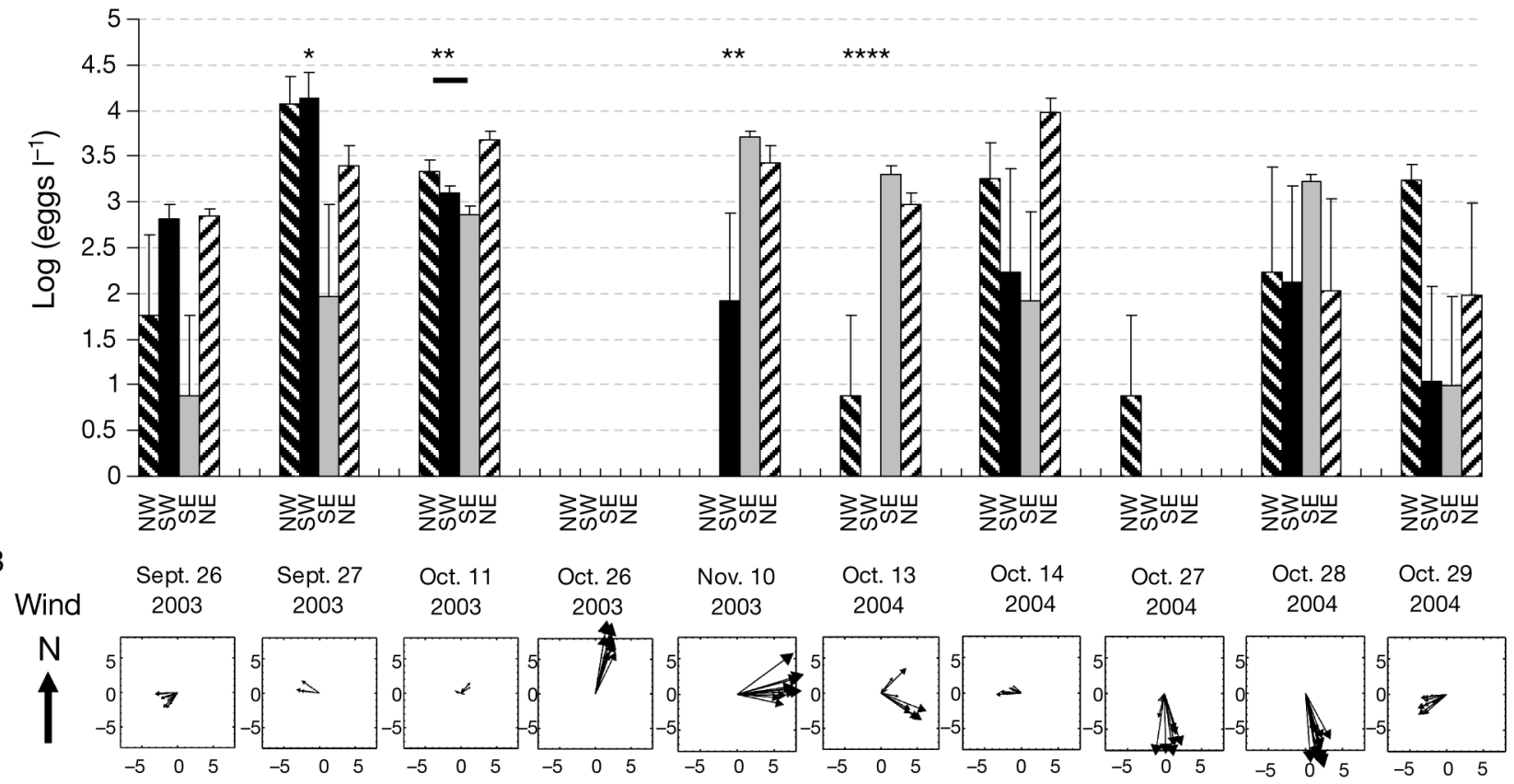

C

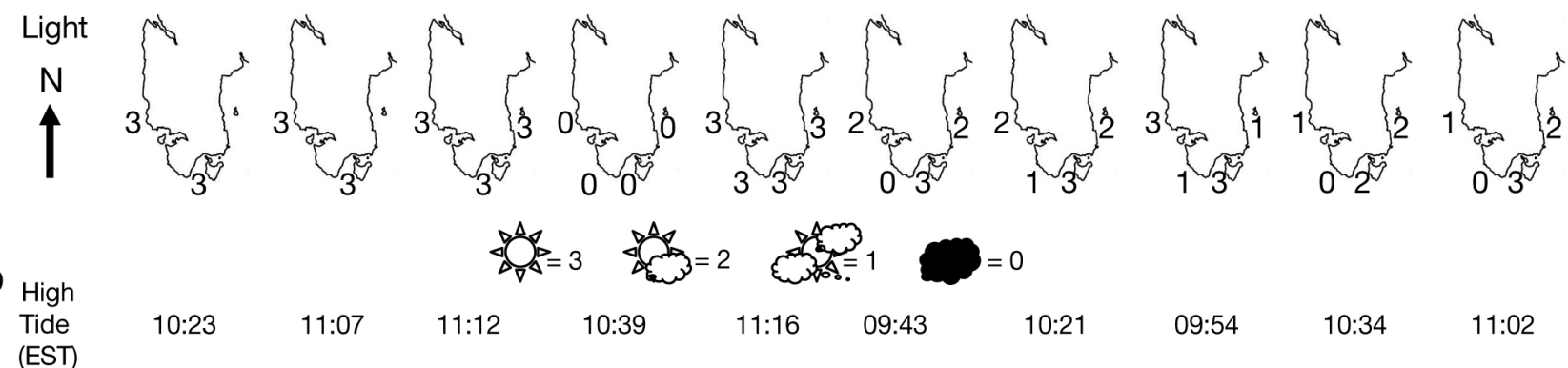

Fig. 2. (A) Egg release at each site (NW, SW, SE, NE). *: significant ANOVA associated with the asynchronous release of

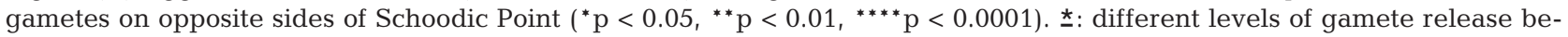
tween northern and southern sites. (B) Wind condition at GoMOOS Buoy 1 during field sampling periods. Direction of arrow indicates wind direction (in angular degrees, north at top), and length of arrow indicates wind speed (in $\mathrm{m} \mathrm{s}^{-1}$ ) as scaled on the $x$ - and $y$-axis. Data at Buoy 1 were missing on 27 September 2003. (C) Categorical irradiance conditions $(0,1,2,3)$ at each site during field sampling periods. (D) Time of high tide during field sampling periods (EST)

$44 \mu \mathrm{mol}$ photons $\mathrm{m}^{-2} \mathrm{~s}^{-1}$ (canopy) on 14 October 2004; and $569 \pm 101 \mu \mathrm{mol}$ photons $\mathrm{m}^{-2} \mathrm{~s}^{-1}$ (aerial) vs. $321 \pm$ $38 \mu \mathrm{mol}$ photons $\mathrm{m}^{-2} \mathrm{~s}^{-1}$ (canopy) on 29 October 2004. Light levels remained above potentiating values (enough light for photosynthesis) at most locations for all days except 26 October 2003. On that day, in addition to low light, water motion was high, which confounds the effects of light and water motion on gamete release.

On all sampling days we collected fertile receptacles and placed them in seawater in containers on the shore to assess gamete release. Gamete release occurred from receptacles on 26 October under such conditions (data not shown), demonstrating that receptacles in the fucoid bed were competent to release gametes underwater that day but did not due to inhibitory levels of light and water motion.

\section{Carbon and nitrogen content of fucoid eggs}

Carbon content per egg ranged from 28 to $32 \mathrm{ng} \mathrm{C}$ $\mathrm{egg}^{-1}$, and nitrogen content was approximately one order of magnitude lower, from 2.03 to $2.52 \mathrm{ng} \mathrm{N}$ $\mathrm{egg}^{-1}$ (Table 2). There was no significant difference in the carbon or nitrogen content of eggs from the 3 sites. These data were used below to calculate the amount of $\mathrm{C}$ and $\mathrm{N}$ pulsed into the environment dur- 
Table 2. Number of eggs released ind. ${ }^{-1}$, carbon and nitrogen content and carbon:nitrogen (atomic ratio) of released Fucus vesiculosus eggs. Values are means \pm SE for samples at each site $(\mathrm{n}=5)$

\begin{tabular}{|c|c|c|c|c|c|c|}
\hline Site & $\begin{array}{l}\text { Number of eggs } \\
\text { released }\left(\times 10^{-3}\right) \text { ind. }^{-1}\end{array}$ & $\begin{array}{l}\text { C per } \\
\text { egg (ng) }\end{array}$ & $\begin{array}{l}\text { N per } \\
\text { egg (ng) }\end{array}$ & $\begin{array}{c}\text { Egg C } \\
\left.\text { (mg ind. } .^{-1}\right)\end{array}$ & $\begin{array}{c}\text { Egg N } \\
\text { (mg ind.-1) }\end{array}$ & Eggs C:N \\
\hline Newport Cove & $199.5 \pm 48.1$ & $28.37 \pm 1.87$ & $2.03 \pm 0.14$ & $5.54 \pm 1.16$ & $0.40 \pm 0.08$ & $16.3 \pm 0.2$ \\
\hline Ledges & $492.0 \pm 106.8$ & $30.85 \pm 2.02$ & $2.52 \pm 0.22$ & $15.01 \pm 3.46$ & $1.21 \pm 0.29$ & $14.5 \pm 0.5$ \\
\hline Seawall & $251.4 \pm 59.4$ & $31.78 \pm 2.91$ & $2.48 \pm 0.21$ & $7.69 \pm 1.72$ & $0.56 \pm 0.15$ & $15.2 \pm 0.3$ \\
\hline Overall mean & $314.3 \pm 71.4$ & $30.3 \pm 2.3$ & $2.3 \pm 0.2$ & $9.4 \pm 2.1$ & $0.7 \pm 0.2$ & \\
\hline
\end{tabular}

ing gamete release. The effect of storage time before processing samples on the results was not significant $\left(C\right.$, linear regression, $\mathrm{r}^{2}=0.056, \mathrm{p}=0.40 ; \mathrm{N}$, linear regression, $\mathrm{r}^{2}=0.003, \mathrm{p}=0.82$ ).

\section{Refined model applied to historical data: regional patterns and reproductive subsidies}

A logistic regression of field data demonstrates that gamete release occurs $(\mathrm{p}<0.05)$ with Beaufort values $<4.45$ (Fig. 3). The threshold value at which any gamete release occurs corresponds to a wind speed $<6.6 \mathrm{~m} \mathrm{~s}^{-1}$. Applying these values to improve the Berndt et al. (2002) model, irradiance categories and wind thresholds were used to estimate when reproduction by Fucus vesiculosus would be possible within the GOM at the 5 defined regions (see 'Materials and methods').

Our model, integrated with archival environmental data (ca. $10 \mathrm{~d}$ for each mo for September-December during 1985-2006), hindcast distinctive patterns of reproduction in the GOM. In general, there was a great deal of variability across the regions and over the years surveyed (Figs. $4 \& 5$ ). When evaluating the entire GOM, levels of reproductive potential varied

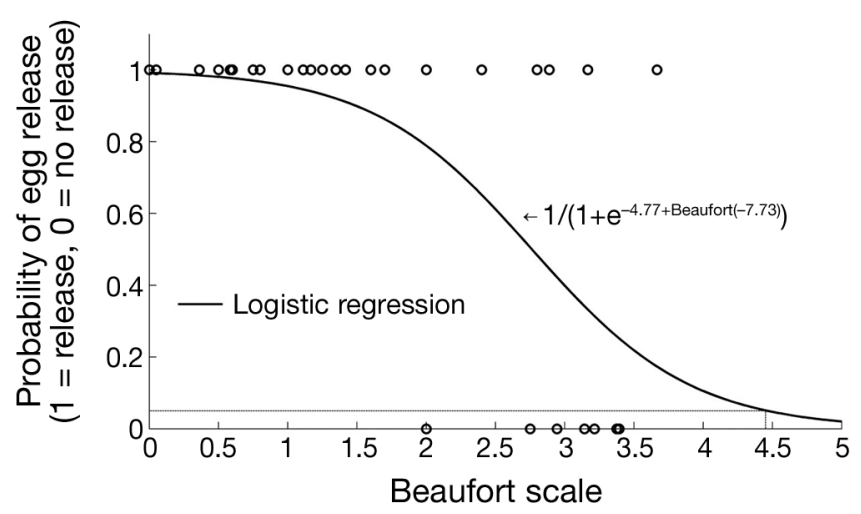

Fig. 3. Logistic regression of the relationship between Beaufort scale for wind speed and egg release across years; on average, $27 \%$ of days when gamete release could have occurred had conditions that would allow gamete release. Reproduction was possible on the fewest days (12\%) in 1991 and on the most days in 2003 (45\%). Ideal conditions for reproduction were fewest for Portsmouth, NH $(17 \%$ of days), at similar levels for Boston, MA ( $26 \%$ of days) and Portland, ME (28\% of days), and higher at Penobscot Bay, ME (44\% of days) and Bar Harbor, ME (38\% of days). The climatological composition of wind in the autumn was relatively uniform across all regions in the GOM (Fig. 6). In general, western winds are most common, and northern winds occur least frequently (Fig. 6).

Remarkably, the model hindcast that the number of days when reproduction occurred increased significantly at 4 of the 5 regions from 1985-2006 (linear regressions, Table 3). Boston, MA, did not show any significant increase in the number of permissive days. To investigate whether this significant trend was driven by wind speed or irradiance, linear regressions of wind speed over years were performed, and there were no significant trends at any location (data not shown). Therefore, we hypothesize that the number of sunny (non-foggy) periods on the coast during September to December has increased, permitting more opportunities for fucoid reproduction to occur in the GOM.

Combining nutrient content of fucoid eggs (mg C or mg N ind. ${ }^{-1}$; Table 2) with fucoid population statistics at Schoodic Point revealed a large local input of $\mathrm{C}$ and $\mathrm{N}$ as a result of egg release. With a linear coastline of $7 \times 10^{3} \mathrm{~m}$ and an average zone width of $18.7 \pm 6 \mathrm{~m}$, we calculated the potential input of nutrients each $2 \mathrm{wk}$ reproductive period across Schoodic Point as $7.6 \times 10^{4} \mathrm{~g} \mathrm{C}$ and $5.6 \times 10^{3} \mathrm{~g} \mathrm{~N}$, or $10.8 \mathrm{~g} \mathrm{C}$ $\mathrm{m}^{-1}$ linear coastline and $0.8 \mathrm{~g} \mathrm{~N} \mathrm{~m}^{-1}$ linear coastline. We further calculated the potential input of carbon and nitrogen due to egg release at Schoodic Point over the fall (September-December) reproductive season to be $6.1 \times 10^{5} \mathrm{~g} \mathrm{C}$ and $4.5 \times 10^{4} \mathrm{~g} \mathrm{~N}$, respectively. 


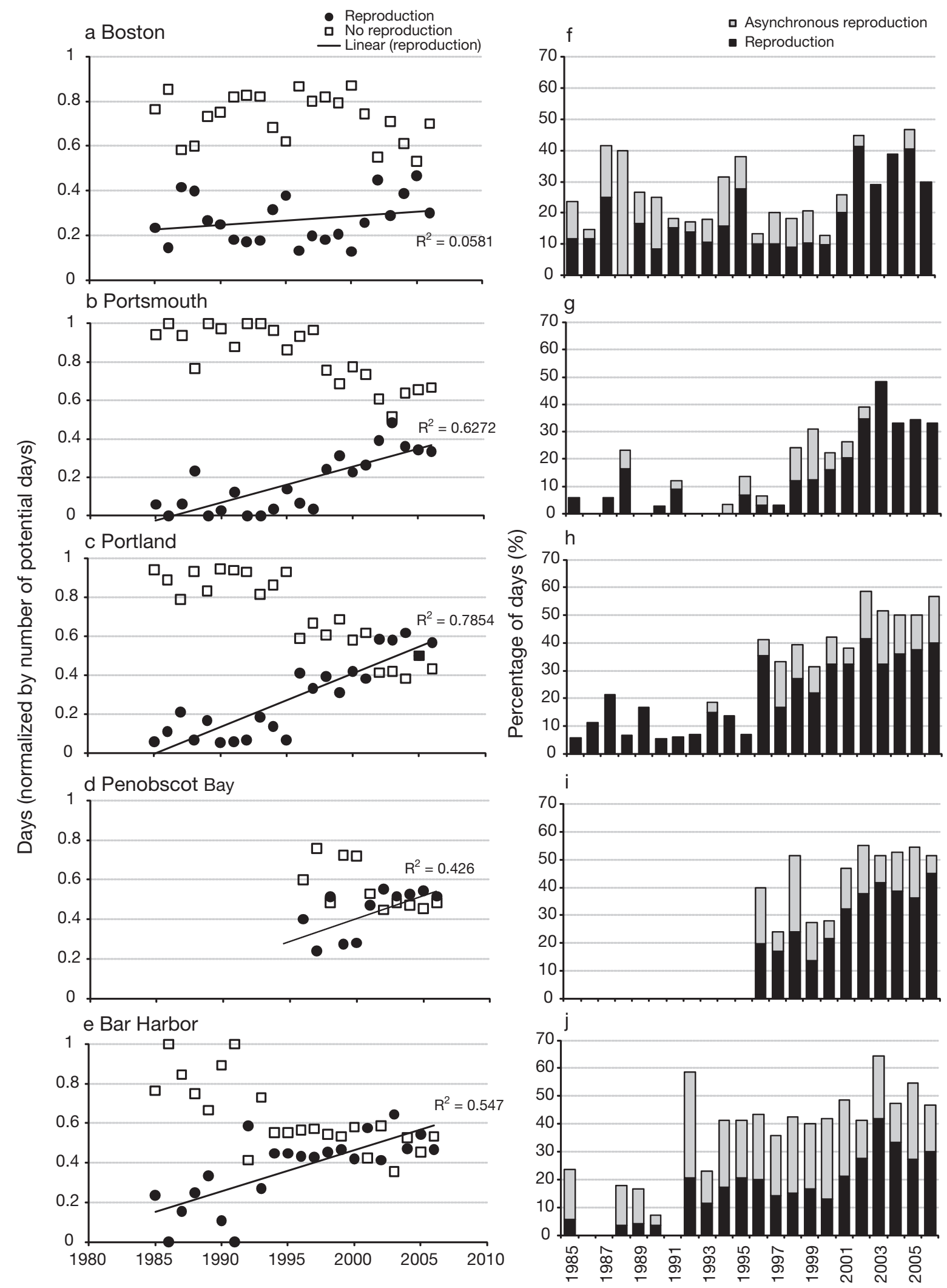

Fig. 4. Temporal (1985-2006) model results for each regional location. (a-e) Number of days that the model hindcast reproduction (= synchronous and asynchronous) to occur. Linear relationships plotted for reproduction (solid line). (f-j) \% of days when reproduction was either synchronous (black bar) or asynchronous (gray bar) on opposite sides of coastal points 


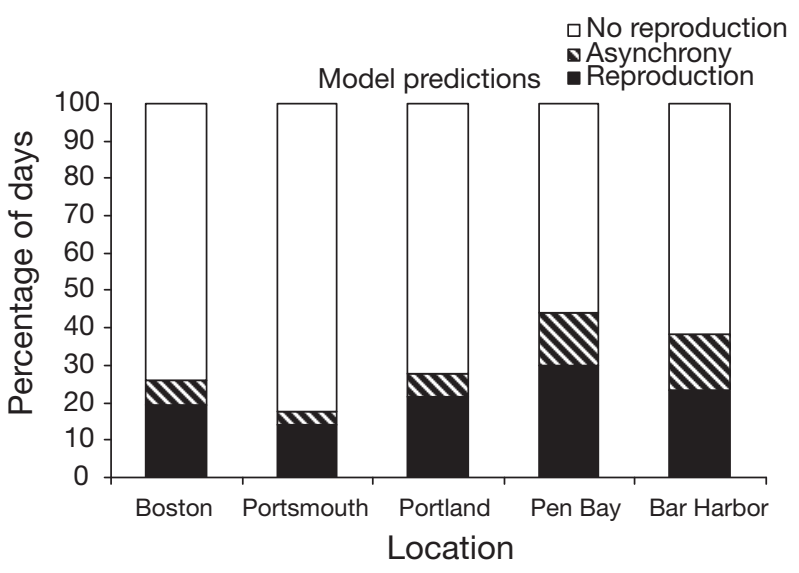

Fig. 5. Hindcast predictions. Days (\%, 1985-2006) when gamete release occurred on both sides of a coastal point (= reproduction), with spatial asynchrony across a coastal point, or did not occur anywhere. Pen Bay: Penobscot Bay

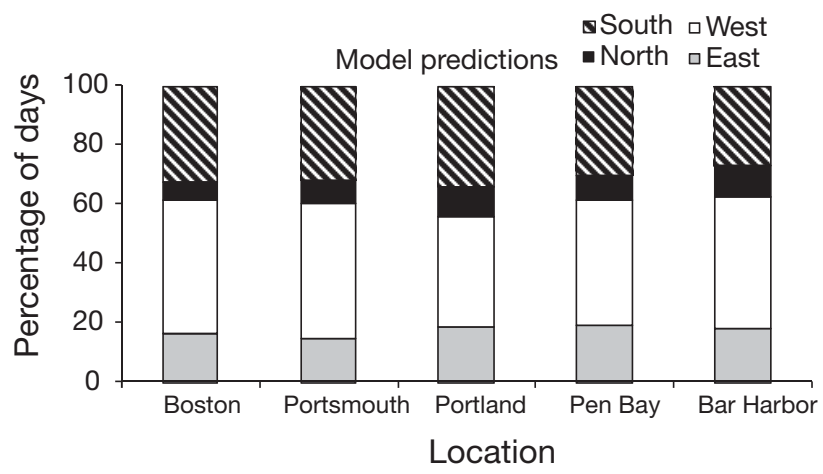

Fig. 6. Average direction of wind over 1985-2006 at each location in the Gulf of Maine. Pen Bay: Penobscot Bay

Table 3. Summary of regressions of hindcast days of fucoid reproduction with time (1985-2006) for each region. A positive slope indicates a trend for increased reproduction $\mathrm{yr}^{-1}$ over the study period

\begin{tabular}{|lcccr|}
\hline Region & $\mathrm{n}$ & $\begin{array}{c}\text { Correlation } \\
\text { Coefficient }\end{array}$ & Slope & $\mathrm{p}$ \\
\hline Boston & 22 & 0.24 & + & 0.28 \\
Portsmouth & 22 & 0.79 & + & $<\mathbf{0 . 0 5}$ \\
Portland & 22 & 0.88 & + & $<\mathbf{0 . 0 5}$ \\
Penobscot Bay & $11^{\mathrm{a}}$ & 0.65 & + & $\mathbf{< 0 . 0 5}$ \\
Bar Harbor & 22 & 0.74 & + & $<\mathbf{0 . 0 5}$ \\
a1985-1995 data missing for Penobscot Bay & \\
\hline
\end{tabular}

\section{DISCUSSION}

Our field studies demonstrate that spatially asynchronous environmental conditions across a coastal point result in spatially asynchronous gamete release. Wind speed and wind direction set up condi- tions for geographically asynchronous gamete release on $40 \%$ of days. For another $20 \%$ of field days, low levels of irradiance and/or high levels of water motion resulted in little or no reproduction. Beaufort sea state predicted hydrodynamic conditions that inhibited the quantity of eggs released. The model is robust for easterly and westerly winds but needs to be improved for northern winds. The regional, GOM model of reproduction for fucoid algae, when integrated with archival environmental data, demonstrates temporal and spatial patterns of variability in reproduction, and holds great promise in examining the response of reproduction in Fucus vesiculosus to ocean-climate variability. The model also predicts times when responses from other GOM organisms may occur, due to the energy input represented by gamete release from one of the most common macrophytes in the GOM and entire north Atlantic.

Interactions among environmental factors and reproduction provide insight about scales at which populations are connected. One might anticipate that reproductive asynchrony on opposite sides of a coastal point would result in genetically distinct populations on either side of a coastal promontory. However, Muhlin et al. (2008) characterized the population genetic structure of Fucus vesiculosus at the same spatial scales as the present study and demonstrated that, although there is significant genetic differentiation between populations, differentiation does not correspond to eastern versus western sides of coastal promontories. By integrating genetic and nearshore circulation data with a laboratory study of gamete longevity, any fine-scale genetic structure of populations in $F$. vesiculosus that might result from asymmetric gamete release was demonstrated to be swamped out by distant dispersal of gametes from storm-detached, rafting, reproductive adults (Muhlin et al. 2008). Among the GOM fucoid algae, only 2 species, F. vesiculosus and Ascophyllum nodosum, possess air bladders that provide for rafting. However, other marine biota, including other fucoids (e.g. F. spiralis, F. distichus), may become entangled in a buoyant raft (e.g. Coleman \& Brawley 2005). Thus, rafting-mediated gene flow may be a general phenomenon by which fine-scale genetic differentiation due to spatial asymmetry in gamete release is suppressed.

Results of the regional model suggest that coastal areas in the GOM that are homogenous in topography and weather patterns (wind speed, direction, and cloud cover) will have similar patterns of reproduction. For example, the model predicts that GOM 
Regions 4 and 5 (Penobscot Bay and Bar Harbor) have the most days of gamete release, as well as the most days with spatial asynchrony in reproduction over local scales.

Although there is congruence between the environmental conditions observed during field sampling and results of the model (ca. $72 \%$ ), the model has 3 main limitations. First, levels of irradiance may be different at a particular location relative to the nearest meteorological station (e.g. due to coastal fog). As a result, the number of days when hindcast meteorological data indicated overcast conditions may be conservatively high because of the location of the sensors, and the model may underestimate when reproduction can occur. For example, irradiance levels observed at Schoodic Point on 2 d during our field study (26 and 27 September 2003) were reported as overcast days in the meteorological data, but observed irradiances $3 \mathrm{~h}$ prior to high tide of 582 to 1100 umols photons $\mathrm{m}^{-2} \mathrm{~s}^{-1}$ (permissive for gamete release) were measured. In addition, our model was not robust in predicting whether or not gamete release occurred during Category 1 conditions. Category 1 corresponds to above-water light levels of 201 to $300 \mu \mathrm{mol}$ photons $\mathrm{m}^{-2} \mathrm{~s}^{-1}$ and canopy-level light levels approximately one-half of the above-water measurements. Second, wind speeds obtained from the buoy and meteorological stations may be greater than wind speeds at the shore. To explore the degree to which wind speeds differ on land versus at buoys, archival data from the Portland Jetport and GoMOOS Buoy C were compared for SeptemberDecember 2002. Buoy and airport wind speeds were positively correlated (linear correlation, $r^{2}=0.640$, $\mathrm{p}<0.001$ ), but wind conditions at the jetport were, on average, $2.4 \mathrm{~m} \mathrm{~s}^{-1}$ slower than wind speeds documented at the buoy. Therefore, if anything, the model may be conservative and may underestimate the number of days when reproduction can occur. Third, our model has weak predictability for winds that are in a direction that blow across a landmass. In our field study, model predictions were weak during northerly winds. Two days (27 and 28 October 2004) had strong northern winds, and gamete release was markedly different on these 2 days. In general, gamete release on the tidal series of 27-29 October 2004 was incongruent with the model, and we are unable to explain the exceptional character of gamete release during that tidal series. More field experiments with a large array of within site anemometers and continuously recording light meters at the surface and in the canopy might help gamete release at threshold light conditions (between Cate- gories 1 and 2) and during northern winds, which are uncommon.

Fucus vesiculosus is a good candidate for future studies of how atmospheric forcing (i.e. local weather), such as the North Atlantic Oscillation (NAO), may directly affect marine species because of the strong effect of local conditions of irradiance and water motion on reproduction. For example, positive NAO years tend to have warmer, milder conditions. We would predict that positive NAO years would be favorable for reproduction in F. vesiculosus, whereas negative NAO years, with their significantly different wind compositions and greater number of stormy days (=low irradiance, high levels of water motion) would be associated with a marked decrease in the number of days when gamete release occurs. Studies have focused on the coupled responses of ocean and atmospheric physics (e.g. Visbeck et al. 2003, Davies \& Johnson 2006), and phytoplankton, zooplankton, fish, whales, and seabird communities (e.g. Greene \& Pershing 2000, 2007, Drinkwater et al. 2003, Pershing et al. 2005, Townsend et al. 2010) to climate variability associated with the NAO. These studies demonstrate that the relationship between the NAO and community dynamics of marine biota is linked through atmospheric changes that have oceanographic responses (e.g. changes in circulation patterns, changes in salinity) that directly affect phytoplankton communities (Greene \& Pershing 2000, 2007, Ji et al. 2007, Townsend et al. 2010), which mediate changes in higher trophic communities in marine ecosystems (Drinkwater et al. 2003).

Our regional model for gamete release refined components of Berndt et al.'s (2002) preliminary model of reproduction. Although we could not improve threshold levels of irradiance, our model did refine the upper threshold values for wind speed. Berndt et al. (2002) constructed a 2-tiered model for reproduction; the first tier was for 'best' days for reproduction. These days corresponded to wind speed values that were $<2.0 \mathrm{~m} \mathrm{~s}^{-1}$, and 'other possible' days for release to occur had wind speeds ranging from 2.0 to $10.0 \mathrm{~m}$ $\mathrm{s}^{-1}$. The present study lowered the threshold value for wind speed from 10.0 to $6.6 \mathrm{~m} \mathrm{~s}^{-1}$. This refinement will enable future studies to look at how possible changes in wind speed due to shifting climate may induce shifts in timing of reproduction.

Fucoid gamete release contributes a significant spatial subsidy to local intertidal and subtidal communities and was a previously uncharacterized component of the GOM C and $\mathrm{N}$ budget. Further studies are required to calculate regional nutrient inputs into the nearshore environment due to Fucus vesiculosus 
reproduction in the GOM, particularly to include the nutrient inputs from mucilage and excess sperm. A preliminary calculation, using coastal linear distances, zone widths, and density data for F. vesiculosus at locations from Rockport, MA to Jonesport, ME (authors' unpubl. data), suggests a potential, pulsed subsidy per $14 \mathrm{~d}$ cycle of $2.8 \times 10^{6} \mathrm{~g} \mathrm{C}$ and $2.2 \times 10^{5} \mathrm{~g}$ $N$. In addition to $F$. vesiculosus, other fucoid algae, particularly Ascophyllum nodosum, are abundant in the GOM. Thus, the collective subsidy due to fucoid reproduction is likely to affect local herbivores, omnivores, and detritivores; because the release of gametes into the environment occurs in response to predictable physical factors, it may have led to adaptive behaviors of intertidal animals, with larger consequences for community metabolism and nutrient cycling. Wild et al. (2008) quantified effects of coral gamete release on pelagic and benthic processes on the Great Barrier Reef. Their study demonstrated that a pulse of coral gametes over 1 or 2 nights caused a significant increase in particulate organic matter, which increased microbial decomposition and enhanced primary productivity over the course of weeks (Wild et al. 2008). Receptacles of F. vesiculosus typically discharge their mature gametes on 1 to $3 \mathrm{~d}$ of high tides with suitable environmental conditions every semilunar (14 d) cycle, over the course of months (September to December), and receptacles containing mature gametes often occur through spring. A wider test of gamete release in F. vesiculosus in the entire GOM would be helpful because one cannot interpret whether reproduction occurs by the presence of receptacles alone. For example, mature gametes in receptacles damaged by freezing are not released (Speransky et al. 1999). Predictable, bimonthly pulses of gametes and reproductive mucilage could have significant community effects over the order of weeks or months. Many organisms may use fucoid gametes and associated mucilage as food. Climate-induced changes to reproduction of marine organisms such as fucoids may initiate unexpected effects on nearshore marine communities.

Acknowledgements. We thank T. Tripp (University of Maine Physics Shop) for construction and consultation on the pumps; L. Schick (Darling Marine Center, University of Maine) for assistance with the CHNOS analyzer; the National Park Service staff at Schoodic Point, Acadia National Park, ME for support; and J. Tjepkema (University of Maine) for use of a light meter. We thank A. Mathieson (University of New Hampshire) for insightful discussion and express gratitude to W. Halteman and R. Weatherbee (University of Maine) for statistical expertise. We are grateful to 3 anonymous reviewers for their helpful comments and to our many field assistants: M. Austin, R. and A. Barton, N. Blouin, J. Koester, K. Legaard, G. and R. Levin, J. Muhlin, D. Olson, E. Owen, C. Rickards-Rees, R. Weatherbee, C. Weight, and J. Winn. This research was funded by a National Science Foundation grant (OCE- 099043 to SHB), a Phycological Society of America student research award (to J.F.M.), a Fitz Eugene Dixon Fellowship (Acadia Partners for Science and Learning grant to J.F.M.), and a University of Auckland Research and Study Leave grant (to T.A.V.R.). J.F.M. held a NSF GK-12 fellowship through the University of Maine (DGE-0231642) during part of this work.

\section{LITERATURE CITED}

Babcock RC, Bull GD, Harrison PL, Heyward AJ, Oliver JK, Wallace CC, Willis BL (1986) Synchronous spawning of 105 scleratinian coral species on the Great Barrier Reef. Mar Biol 90:379-394

> Bartels-Hardege HD, Hardege JD, Zeeck E, Muller C, Wu BL, Zhu MY (1996) Sex pheromones in marine polychaetes V: a biologically active volatile compound from the coelomic fluid of female Nereis (Neanthes) japonica (Annelida Polychaeta). J Exp Mar Biol Ecol 201:275-284

Berndt ML, Callow JA, Brawley SH (2002) Gamete concentrations and timing and success of fertilization in a rocky shore seaweed. Mar Ecol Prog Ser 226:273-285

> Bishop MJ, Coleman MA, Kelaher BP (2010) Cross-habitat impacts of species decline: response of estuarine sediment communities to changing detrital resources. Oecologia 163:517-525

Bonardelli JC, Himmelman JH, Drinkwater K (1996) Relation of spawning of the giant scallop, Placopecten magellanicus, to temperature fluctuations during downwelling events. Mar Biol 124:637-649

Brawley SH (1991) The fast block against polyspermy in fucoid algae is an electrical block. Dev Biol 144:94-106

> Brawley SH (1992) Fertilization in natural populations of the dioecious brown alga Fucus ceranoides and the importance of the polyspermy block. Mar Biol 113:145-157

- Brawley SH, Johnson LE (1991) Survival of fucoid embryos in the intertidal zone depends on development stage and microhabitat. J Phycol 27:179-186

Brawley SH, Johnson LE (1992) Gametogenesis, gametes, and zygotes: ecological perspectives on sexual reproduction in the algae. Br Phycol J 27:233-252

> Clifton KE, Clifton LM (1999) The phenology of sexual reproduction by green algae (Bryopsidales) on Caribbean coral reefs. J Phycol 35:24-34

> Coleman MA, Brawley SH (2005) Are life history characteristics good predictors of genetic diversity and structure? A case study of the intertidal alga Fucus spiralis (Heterokontophyta:Phaeophyceae). J Phycol 41:753-762

Crean AJ, Marshall DJ (2008) Gamete plasticity in a broadcast spawning marine invertebrate. Proc Natl Acad Sci USA 105:13508-13513

> Davies AJ, Johnson MP (2006) Coastline configuration disrupts the effects of large-scale climatic forcing, leading to divergent temporal trends in wave exposure. Estuar Coast Shelf Sci 69:643-648

Drinkwater KF, Belgrano A, Borja A, Conversi A and others (2003) The response of marine ecosystems to climate variability associated with the North Atlantic Oscillation. In: Hurrell JW, Kushnir Y, Ottersen G, Visbeck M (eds) The North Atlantic Oscillation: climatic significance and 
environmental impact, Geophysical Monograph 134. American Geophysical Union, Washington, DC, p 211-234 > Duggins DO, Eckman JE (1994) The role of kelp detritus in the growth of benthic suspension feeders in an understory kelp forest. J Exp Mar Biol Ecol 176:53-68

Dumont CP, Roy JS, Himmelman JH (2008) Predation by the sea urchin Strongylocentrotus droebachiensis on capsular egg masses of the whelk Buccinum undatum. J Mar Biol Assoc UK 88:1025-1031

Findlay S, Tenore K (1982) Nitrogen source for a detritivore: detritus substrate versus associated microbes. Science 218:371-373

> Franke ES, Babcock RE, Styan CA (2003) Sexual conflict and polyspermy under sperm-limited conditions: in situ evidence from field simulations with the free-spawning marine echinoid Evechinus chloroticus. Am Nat 160: 485-496

Galvão HM, Fritz AT, Schmaljohann R (1989) Ingestion of gametes by protists: fate of surplus reproductive energy in the sea. Mar Ecol Prog Ser 51:215-220

Gaudette J, Wahle RA, Himmelman JH (2006) Spawning events in small and large populations of the green sea urchin Strongylocentrotus droebachiensis as recorded using fertilization assays. Limnol Oceanogr 51: 1485-1496

Giese AC, Kanatani H (1987) Maturation and spawning. In: Giese AC, Pearse JS, Pearse VB (eds) Reproduction of marine invertebrates. Blackwell Scientific, Boxwood Press, Palo Alto/Pacific Grove, CA, p 251-329

Greene $\mathrm{CH}$, Pershing AJ (2000) The response of Calanus finmarchicus populations to climate variability in the Northwest Atlantic: basin-scale forcing associated with the North Atlantic Oscillation. ICES J Mar Sci 57: 1536-1544

Greene CH, Pershing AJ (2007) Climate drives sea change. Science 315:1084-1085

Harrison PL, Babcock RC, Bull GD, Oliver JK, Wallace CC, Willis BL (1984) Mass spawning in tropical reef corals. Science 223:1186-1189

> Hasse L, Smith SD (1997) Local sea surface wind, wind stress, and sensible and latent heat fluxes. J Clim 10: 2711-2724

> Himmelman JH, Dumont CP, Gaymer CF, Vallieres C, Drolet D (2008) Spawning synchrony and aggregative behaviour of cold-water echinoderms during multispecies mass spawnings. Mar Ecol Prog Ser 361:161-168

> Järnegren J, Tobias CR, Macko SA, Young CM (2005) Egg predation fuels unique species association at deep-sea hydrocarbon seeps. Biol Bull 209:87-93

> Ji R, Davis CS, Chen C, Townsend DW, Mountain DG, Beardsley RC (2007) Influence of ocean freshening on shelf phytoplankton dynamics. Geophys Res Lett 34: L24607. doi:10.1029/2007GL032010

Johnson LE, Brawley SH (1998) Dispersal and recruitment of a canopy-forming intertidal alga: the relative roles of propagule availability and post-settlement processes. Oecologia 117:517-526

Kelaher BP, Levinton JS (2003) Variation in detrital enrichment causes spatio-temporal variation in soft-sediment assemblages. Mar Ecol Prog Ser 261:85-97

- Levitan DR, Fogarty ND, Jara J, Lotterhos KE, Knowlton N (2011) Genetic, spatial, and temporal components of precise spawning synchrony in reef building corals of the Montastraea annularis species complex. Evolution 65: $1254-1270$
Lubchenco J (1983) Littorina and Fucus: effects of herbivores, substratum heterogeneity, and plant escapes during succession. Ecology 64:1116-1123

Lubchenco J, Menge BA (1978) Community development and persistence in a low rocky intertidal zone. Ecol Monogr 48:67-94

> Lüning K, Kadel P, Pang S (2008) Control of reproduction rhythmicity by environmental and endogenous signals in Ulva pseudocurvata (Chlorophyta). J Phycol 44:866-873

> Maier I, Müller DG (1986) Sexual pheromones in algae. Biol Bull 170:145-175

Major KM, Davison IR (1998) Influence of temperature and light on growth and photosynthetic physiology of Fucus evanescens (Phaeophyta) embryos. Eur J Phycol 33: $129-138$

- Manríquez PH, Castilla JC (2010) Fertilization efficiency and gamete viability in the ascidian Pyura praeputialis in Chile. Mar Ecol Prog Ser 409:107-119

Marshall DJ (2002) In situ measures of spawning synchrony and fertilization success in an intertidal, free-spawning invertebrate. Mar Ecol Prog Ser 236:113-119

- Marshall DJ, Semmens D, Cook C (2004) Consequences of spawning at low tide: limited gamete dispersal for a rockpool anemone. Mar Ecol Prog Ser 266:135-142

> Meidel SK, Yund PO (2001) Egg longevity and timeintegrated fertilization in a temperate sea urchin (Strongylocentrotus droebachiensis). Biol Bull 201:84-94

> Minchin D (1992) Multiple species, mass spawning events in an Irish sea lough: the effect of temperatures on spawning and recruitment of invertebrates. Invertebr Reprod Dev 22:229-238

Muhlin JF (2007) Reproductive ecology and characterization of population genetic structure of Fucus vesiculosus Linneaus in the northwestern Atlantic. PhD dissertation, University of Maine, Orono, ME

Muhlin JF, Engel CR, Stessel R, Weatherbee RA, Brawley $\mathrm{SH}$ (2008) The influence of coastal topography, circulation patterns and rafting in structuring populations of an intertidal alga. Mol Ecol 17:1198-1210

Pearson GA, Brawley SH (1996) Reproductive ecology of Fucus distichus (Phaeophyceae): an intertidal alga with successful external fertilization. Mar Ecol Prog Ser 143: 211-223

Pearson GA, Brawley SH (1998) A model for signal transduction during gamete release in the fucoid alga Pelvetia compressa. Plant Physiol 118:305-313

Pearson GA, Serrão EA (2006) Revisiting synchronous gamete release by fucoid algae in the intertidal zone: fertilization success and beyond? Integr Comp Biol 46: 587-597

Pearson GA, Serrão EA, Brawley SH (1998) Control of gamete release in fucoid algae: sensing hydrodynamic conditions via carbon acquisition. Ecology 79:1725-1739

Pearson G, Serrão E, Dring M, Schmid R (2004) Blue and green-light signals for gamete release in the brown alga Silvetia compressa. Oecologia 138:193-201

Pershing AJ, Greene CH, Jossi JW, O'Brien L, Brodziak JKT, Bailey BA (2005) Interdecadal variability in the Gulf of Maine zooplankton community, with potential impacts on fish recruitment. ICES J Mar Sci 62:1511-1523

> Polis GA, Anderson WB, Holt RD (1997) Toward an integration of landscape and food web ecology: the dynamics of spatially subsidized food webs. Annu Rev Ecol Syst 28: 289-316

> Pratchett MS, Gust N, Goby G, Klanten SO (2001) Con- 
sumption of coral propagules represents a significant trophic link between corals and reef fish. Coral Reefs 20: 13-17

Riffell JA, Zimmer RK (2007) Sex and flow: the consequences of fluid shear for sperm-egg interactions. J Exp Biol 210:3644-3660

Serrão EA, Pearson G, Kautsky L, Brawley SH (1996) Successful external fertilization in turbulent environments. Proc Natl Acad Sci USA 93:5286-5290

Serrão EA, Brawley SH, Hedman J, Kautsky L, Samuelsson G (1999) Reproductive success of Fucus vesiculosus in the Baltic Sea. J Phycol 35:254-269

Sewell MA, Levitan DR (1992) Fertilization success in a natural spawning of the dendrochirote sea cucumber Cucumaria miniata. Bull Mar Sci 51:161-166

Simpson CJ, Cary JL, Masini RJ (1993) Destruction of corals and other reef animals by coral spawn slicks on Ningaloo Reef, Western Australia. Coral Reefs 12:185-191

Speransky VS, Speransky SR, Brawley SH (1999) Cryoanalytical studies of freezing damage and recovery in Fucus vesiculosus (Phaeophyceae). J Phycol 35:1264-1275

Spiller DA, Piovoa-Scott J, Wright AN, Yang LH, Takimoto G, Schoener TW, Iwata T (2010) Marine subsidies have multiple effects on coastal food webs. Ecology 91: 1424-1434

Starr M, Himmelman JH, Therriault JC (1990) Direct coupling of marine invertebrate spawning with phytoplankton blooms. Science 247:1071-1074

Starr M, Himmelman JH, Therriault JC (1992) Isolation and properties of a substance from the diatom Phaeodactylum tricornutum which induces spawning in the sea urchin Strongylocentrotus droebachiensis. Mar Ecol Prog Ser 79:275-287

Starr M, Himmelman JH, Therriault JC (1993) Environmental control of green sea urchin, Strongylocentrotus droebachiensis, spawning in the St. Lawrence estuary. Can J
Fish Aquat Sci 50:894-901

Storry KA, Weldrick CK, Mews M, Zimmer M, Jelinski DE (2006) Intertidal coarse woody debris: a spatial subsidy as shelter or feeding habitat for gastropods? Estuar Coast Shelf Sci 66:197-203

Thompson TL, Glenn EP (1994) Plaster standards to measure water motion. Limnol Oceanogr 39:1768-1779

Thorson G (1950) Reproductive and larval ecology of marine bottom invertebrates. Biol Rev Camb Philos Soc 25:1-45

Townsend DW, Rebuck ND, Thomas MA, Karp-Boss L, Gettings RM (2010) A changing nutrient regime in the Gulf of Maine. Cont Shelf Res 30:820-832

Vadas RL, Elner RW (1992) Plant-animal interactions in the northwest Atlantic. In: John DM, Hawkins SJ, Price JH (eds) Plant-animal interactions in the marine benthos. Clarendon Press, Oxford, p 30-60

Visbeck M, Chassignet EP, Curry RG, Delworth TL, Dickson RR Krahmann (2003) The ocean's response to North Atlantic Oscillation variability. In: Hurrell JW, Kushnir Y, Ottersen G, Visbeck M (eds) The North Atlantic Oscillation: climatic significance and environmental impact, Geophysical Monograph 134. American Geophysical Union, Washington, DC, p 113-146

Wild C, Jantzen C, Struck U, Hoegh-Guldberg O, Huettel M (2008) Biogeochemical responses following coral mass spawning on the Great Barrier Reef: pelagic-benthic coupling. Coral Reefs 27:123-132

> Williams ME, Bentley MG (2002) Fertilization success in marine invertebrates: the influence of gamete age. Biol Bull 202:34-42

Yund PO, Meidel SK (2003) Sea urchin spawning in benthic boundary layers: are eggs fertilized before advecting away from females? Limnol Oceanogr 48:795-801

Yund PO, Murdock K, Johnson SL (2007) Spatial distribution of ascidian sperm: two-dimensional patterns and short vs. time-integrated assays. Mar Ecol Prog Ser 341:103-109 
Appendix 1. Egg release, meteorological, and environmental conditions for each field sampling day. A day that had spatially asynchronous gamete release across Schoodic Point is marked in bold. A total of 29 (72\%) out of $40 \mathrm{~d}$ fit the model predictions of Berndt et al. (2002). Three specific sites that did not fit model predictions when gamete release occurred at other sites are marked by $\underline{N}$. At each site for that day, light levels were low

\begin{tabular}{|c|c|c|c|c|c|c|c|c|c|c|c|c|}
\hline $\begin{array}{l}\text { Tidal } \\
\text { cycle }\end{array}$ & $\begin{array}{l}\text { High } \\
\text { tide } \\
(\mathrm{EST})\end{array}$ & $\begin{array}{c}\text { Date } \\
\text { (M DD YY) }\end{array}$ & Site & $\begin{array}{l}\text { Egg } \\
\text { release } \\
\left(\log ^{-1}\right) \\
\left.\text { eggs l }^{-1}\right)\end{array}$ & $\begin{array}{c}\text { Irradiance } \\
(\mu \mathrm{mol} \\
\text { photons } \\
\left.\mathrm{m}^{-2} \mathrm{~s}^{-1}\right)\end{array}$ & $\begin{array}{l}\text { Light } \\
\text { cate- } \\
\text { gory at } \\
\text { site }\end{array}$ & $\begin{array}{c}\text { Light } \\
\text { category } \\
\text { at Bar } \\
\text { Harbor } \\
\text { airport }\end{array}$ & $\begin{array}{l}\text { Wind } \\
\text { at Bar } \\
\text { Harbor } \\
\text { airport } \\
\left(\mathrm{m} \mathrm{s}^{-1}\right)\end{array}$ & $\begin{array}{l}\text { Wind } \\
\text { at } \\
\text { Buoy } 1 \\
\left(\mathrm{~m} \mathrm{~s}^{-1}\right)\end{array}$ & $\begin{array}{c}\text { Difference } \\
\text { between a } \\
\text { buoy and } \\
\text { airport } \\
\text { wind } \\
\left(\mathrm{m} \mathrm{s}^{-1}\right)\end{array}$ & $\begin{array}{c}\text { Wind } \\
\text { direction }\end{array}$ & $\begin{array}{c}\text { Fit } \\
\text { Berndt } \\
\text { et al. } \\
(2002) \\
\text { model }\end{array}$ \\
\hline 1 & $10: 23$ & $\begin{array}{lll}\text { S } & 26 & 03 \\
\text { S } & 26 & 03 \\
\text { S } 26 & 03 \\
\text { S } 26 & 03\end{array}$ & $\begin{array}{l}\text { NW } \\
\text { SW } \\
\text { SE } \\
\text { NE }\end{array}$ & $\begin{array}{l}1.8 \\
2.8 \\
0.9 \\
2.8\end{array}$ & 515 & 3 & 0 & 2.4 & 2.1 & -0.3 & NNE-E & $\begin{array}{l}\mathrm{Y} \\
\mathrm{Y} \\
\mathrm{Y} \\
\mathrm{Y}\end{array}$ \\
\hline 1 & 11:07 & $\begin{array}{lll}\text { S } & 27 & 03 \\
\text { S } & 27 & 03 \\
\text { S } 27 & 03 \\
\text { S } 27 & 03\end{array}$ & $\begin{array}{l}\text { NW } \\
\text { SW } \\
\text { SE } \\
\text { NE }\end{array}$ & $\begin{array}{l}4.1 \\
4.1 \\
2.0 \\
3.4\end{array}$ & 816 & 3 & $\begin{array}{l}0 \\
0\end{array}$ & 2.0 & 3.0 & 1.0 & E - SSE & $\begin{array}{l}\mathbf{Y} \\
\mathbf{Y} \\
\mathbf{Y} \\
\mathbf{Y}\end{array}$ \\
\hline 2 & 11:12 & $\begin{array}{llll}\text { O } & 11 & 03 \\
\text { O } & 11 & 03 \\
\text { O } & 11 & 03 \\
\text { O } & 11 & 03\end{array}$ & $\begin{array}{l}\text { NW } \\
\text { SW } \\
\text { SE } \\
\text { NE }\end{array}$ & $\begin{array}{l}3.3 \\
3.1 \\
2.9 \\
3.7\end{array}$ & $\begin{array}{c}1006 \\
805 \\
1200\end{array}$ & $\begin{array}{l}3 \\
3 \\
3\end{array}$ & $\begin{array}{l}3 \\
3 \\
3 \\
3\end{array}$ & 0.9 & 0.9 & 0 & $\mathbf{S}$ & $\begin{array}{l}\mathbf{Y} \\
\mathbf{Y} \\
\mathbf{Y} \\
\mathbf{Y}\end{array}$ \\
\hline 3 & $10: 39$ & 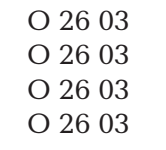 & $\begin{array}{l}\text { NW } \\
\text { SW } \\
\text { SE } \\
\text { NE }\end{array}$ & $\begin{array}{l}0 \\
0 \\
0 \\
0\end{array}$ & $\begin{array}{c}107 \\
94 \\
102 \\
102\end{array}$ & $\begin{array}{l}0 \\
0 \\
0 \\
0\end{array}$ & $\begin{array}{l}0 \\
0 \\
0 \\
0\end{array}$ & 6.5 & 7.5 & 1.0 & S-SSW & $\begin{array}{l}\mathrm{Y} \\
\mathrm{Y} \\
\mathrm{Y} \\
\mathrm{Y}\end{array}$ \\
\hline 4 & 11:16 & $\begin{array}{ll}\text { N } 10 & 103 \\
\text { N } 10 & 03 \\
\text { N } 10 & 03 \\
\text { N } 10 & 03\end{array}$ & $\begin{array}{l}\text { NW } \\
\text { SW } \\
\text { SE } \\
\text { NE }\end{array}$ & $\begin{array}{c}0 \\
1.9 \\
3.7 \\
3.4\end{array}$ & $\begin{array}{c}1117 \\
567 \\
785 \\
927\end{array}$ & $\begin{array}{l}3 \\
3 \\
3 \\
3\end{array}$ & $\begin{array}{l}3 \\
3 \\
3 \\
3\end{array}$ & 3.4 & 7.0 & 4.4 & WSW & $\begin{array}{l}\mathbf{Y} \\
\mathbf{Y} \\
\mathbf{Y} \\
\mathbf{Y}\end{array}$ \\
\hline 5 & 9:43 & $\begin{array}{llll}\text { O } & 13 & 04 \\
\text { O } & 13 & 04 \\
\text { O } & 13 & 04 \\
\text { O } & 13 & 04\end{array}$ & $\begin{array}{l}\text { NW } \\
\text { SW } \\
\text { SE } \\
\text { NE }\end{array}$ & $\begin{array}{c}0.9 \\
0 \\
3.3 \\
3.0\end{array}$ & $\begin{array}{l}337 \\
120 \\
708 \\
306\end{array}$ & $\begin{array}{l}2 \\
0 \\
3 \\
2\end{array}$ & $\begin{array}{l}2 \\
2 \\
2 \\
2\end{array}$ & 3.4 & 5.3 & 1.9 & WNW & $\begin{array}{l}\mathbf{Y} \\
\mathbf{Y} \\
\mathbf{Y} \\
\mathbf{Y}\end{array}$ \\
\hline 5 & $10: 21$ & $\begin{array}{lll}\text { O } & 14 & 04 \\
\text { O } & 14 & 04 \\
\text { O } & 14 & 04 \\
\text { O } & 14 & 04\end{array}$ & $\begin{array}{l}\text { NW } \\
\text { SW } \\
\text { SE } \\
\text { NE }\end{array}$ & $\begin{array}{l}3.3 \\
2.2 \\
1.9 \\
4.0\end{array}$ & $\begin{array}{c}411 \\
265 \\
1003 \\
350\end{array}$ & $\begin{array}{l}2 \\
1 \\
3 \\
2\end{array}$ & $\begin{array}{l}3 \\
3 \\
3 \\
3\end{array}$ & 1.9 & 1.5 & -0.4 & E-ESE & $\begin{array}{l}\mathrm{Y} \\
\mathrm{N} \\
\mathrm{Y} \\
\mathrm{Y}\end{array}$ \\
\hline 6 & $9: 54$ & $\begin{array}{l}\text { O } 2704 \\
\text { O } 2704 \\
\text { O } 2704 \\
\text { O } 2704\end{array}$ & $\begin{array}{l}\text { NW } \\
\text { SW } \\
\text { SE } \\
\text { NE }\end{array}$ & $\begin{array}{c}0.9 \\
0 \\
0 \\
0\end{array}$ & $\begin{array}{l}550 \\
267 \\
880 \\
246\end{array}$ & $\begin{array}{l}3 \\
1 \\
3 \\
1\end{array}$ & $\begin{array}{l}3 \\
3 \\
3 \\
3\end{array}$ & 4.3 & 7.0 & 2.7 & N-NNW & $\begin{array}{l}\mathrm{N} \\
\mathrm{N} \\
\mathrm{N} \\
\mathrm{N}\end{array}$ \\
\hline 6 & $10: 34$ & $\begin{array}{lll}\text { O } & 28 & 04 \\
\text { O } & 28 & 04 \\
\text { O } 28 & 04 \\
\text { O } & 28 & 04\end{array}$ & $\begin{array}{l}\text { NW } \\
\text { SW } \\
\text { SE } \\
\text { NE }\end{array}$ & $\begin{array}{l}2.2 \\
2.1 \\
3.2 \\
2.0\end{array}$ & $\begin{array}{c}293 \\
63 \\
448 \\
351\end{array}$ & $\begin{array}{l}1 \\
0 \\
2 \\
2\end{array}$ & $\begin{array}{l}3 \\
3 \\
3 \\
3\end{array}$ & 4.3 & 9.9 & 5.6 & N-NNW & $\begin{array}{l}\mathrm{N} \\
\mathrm{N} \\
\mathrm{N} \\
\mathrm{N}\end{array}$ \\
\hline 6 & $11: 02$ & $\begin{array}{l}\text { O } 2904 \\
\text { O } 2904 \\
\text { O } 2904 \\
\text { O } 2904\end{array}$ & $\begin{array}{l}\text { NW } \\
\text { SW } \\
\text { SE } \\
\text { NE }\end{array}$ & $\begin{array}{l}3.2 \\
1.0 \\
1.0 \\
2.0\end{array}$ & $\begin{array}{l}288 \\
137 \\
569 \\
409\end{array}$ & $\begin{array}{l}1 \\
0 \\
3 \\
2\end{array}$ & $\begin{array}{l}2 \\
2 \\
2 \\
2\end{array}$ & 1.8 & 2.5 & 0.7 & NW-NNW & $\begin{array}{l}\frac{N}{N} \\
\frac{Y}{Y} \\
Y\end{array}$ \\
\hline
\end{tabular}

